\title{
Investigating EFL Students' Perception of English Vocabulary Acquisition Through Online Gaming
}

\author{
Lusy Angraeni \\ lusyangraeni.aba@umi.ac.id \\ Chuzaimah \\ chuzaimah.aba@umi.ac.id \\ Fadli Nasir \\ Fadlinasir19@gmail.com \\ Akademi Bahasa Asing UMI
}

\begin{abstract}
This study focuses on university students' opinion about secondary vocabulary acquisition through an online game. This study employs a descriptive quantitative method using questionnaire to gather the data. The whole population in this study was the fourth semester students of Akadami Bahasa Asing UMI. The samples were students who frequently play online game specifically Player Unknown's Battleground (pubg), from class $\mathrm{C} 1$ until C4. The sample was taken by using purposive sampling technique. This research was conducted by distributing questionnaires to students who were respondents, after which they were input and analyzed through the SPSS program. The findings revealed that based on the 12 items that were given, the most chosen by students was item 2 and 8 , students who understood the meaning of new vocabularies when playing games and students who made a new vocabulary list and wrote the translation in Indonesian were the opinions most chosen by students with an occasional scale of $60 \%$.
\end{abstract}

Keyword : Student Perception, Vocabulary, Online Gaming.

\section{INTRODUCTION}

Learning a new language cannot be separated from vocabulary. Meaning that in learning a new language people have to know it's vocabulary. Vocabulary can be defined in various ways. Defines vocabulary is the knowledge of meaning words. To term vocabulary has range of meanings. 
for example, some teachers use the term to mean sight-word vocabularies. Referring to students immediate recognition of words in print; other teachers refer to words students understand as their meaning vocabularies. Still other teachers use the term to mean listening vocabularies, or students understanding of words that they hear in spoken language. Content teachers use the term academic vocabulary to refer to content-specific words. Within this section, we use to term vocabulary to refer to students understanding of oral and print words. Vocabularies include conceptual knowledge of words that goes well beyond a simple dictionary definition. Students vocabulary knowledge is a building process thatboccurs over time as they make connection to other words, learn examples and non-examples of the word and related words, and use the word accurately within the context of the sentence (Snow, Griffin, \& Burns, 2005).

The other definition of vocabulary states from Hatch and Brown (1995:1), they say that vocabulary refers to a list or set of a particular language or a list or set of words that individual speakers of language might use. Hatch and Brown (1995: 1) also state that vocabulary is the only system involved of alphabetical order. Based on those statements, it can be assumed that vocabulary is a list of words as a basic component of language proficiency which has a form or expression and contains of aspects, they are meaning, use of word, form (pronunciation and spelling). As we know that vocabularies are used quite often in the teaching and learning English language. To help the students in improving vocabulary mastery, the writer will use online game as a technique of teaching vocabulary .

There are many techniques in improving vocabulary such as; by using songs, picture and game. First, improving vocabulary by using songs which is good for teaching vocabulary by using tape, cassette, and song lyric as media. The obstacle in using this technique is rather difficult to appropriate vocabularies in song's lyric. The second is by using pictures which fun for use teaching vocabulary, it can make the class will be more fun. But this technique already researched by many researchers. And the last is by using games which is better choice for senior high school. The class will be more cheerful and joyful and the students will not get bored. It will be easier for them in mastering and improving their vocabulary. Improving vocabulary by using game has some advantages. First, in general children are found of games. They always play game in their lives. They spend of more free time to play. Second, game offers natural communication context among them. By playing games they sometimes forget about their shy. Third, games can motivate children to speak in English language that they learn.

There are many type of games, one of them is an online game. The role of technology as an alternative tool for instruction of English foreign language learners increase as educators recognize its possibilities to create both independent and collaborative learning environments in which students can acquire, immerse and practice a new language (Butler-Pascoe, 1997). 
Through the use of the internet, word processors, video games multimedia and practice programs, student can engage their English in learning vocabulary. Therefore, this study focuses on the potential of online game as a powerful tool to improve students' vocabulary. Based on the statements above, the authors decided to study on students' preception on learning English Vocabulary through online game at Foreign Language Academy of UMI".

\section{LITERATURE OF REVIEW}

An online game is a video game that is either partially or primarily played through the Internet or any other computer network available. Online games are ubiquitous on modern gaming platforms, including PCs, consoles and mobile devices, and span many genres, including first-person shooters, strategy games and massively multiplayer online role-playing games (Rollings, 2006). The design of online games can range from simple textbased environments to the incorporation of complex graphics and virtual worlds. The existence of online components within a game can range from being minor features, such as an online leaderboard, to being part of core gameplay, such as directly playing against other players. Many online games create their own online communities, while other games, especially social games, integrate the players' existing real-life communities.

PlayerUnknown's Battlegrounds (PUBG) is an online multiplayer battle royale game developed and published by PUBG Corporation, a subsidiary of South Korean video game company Bluehole. The game is based on previous mods that were created by Brendan "PlayerUnknown" Greene for other games, inspired by the 2000 Japanese film Battle Royale, and expanded into a standalone game under Greene's creative direction. In the game, up to one hundred players parachute onto an island and scavenge for weapons and equipment to kill others while avoiding getting killed themselves. The available safe area of the game's map decreases in size over time, directing surviving players into tighter areas to force encounters. The last player or team standing wins the round. Battlegrounds was first released for Microsoft Windows via Steam's early access beta program in March 2017, with a full release on December 20, 2017. That same month, the game was released by Microsoft Studios for the Xbox One via its Xbox Game Preview program, and officially released in September 2018. The same year, a free-toplay mobile version for Android and iOS was released, in addition to a port for the PlayStation 4. Battlegrounds is one of the best-selling and most-played video games of all time, selling over fifty million copies worldwide by June 2018 , with over 400 million players in total when including the mobile version. Battlegrounds received positive reviews from critics, who found that while the game had some technical flaws, it presented new types of gameplay that could be easily approached by players of any skill level and was highly 
replayable. The game was attributed to popularizing the battle royale genre, with a number of unofficial Chinese clones being produced following its success. The game also received several Game of the Year nominations, among other accolades. PUBG Corporation has run several small tournaments and introduced in-game tools to help with broadcasting the game to spectators, as they wish for it to become a popular esport.

\section{METHOD}

This research used descriptive quantitative method (Sugiyono, 2008). The method was applied to analyze, and to classify the result of investigation students' opinion about learning vocabulary through online game. In this study, the participants were undergraduate students of Universitas Muslim Indonesia who were in their 4th semester at the English Department of Akademi Bahasa Asing UMI.

The data collection for this study used questionnaires and interviews. The questionnaire consists of 12 questions used to see students' perceptions of Vocabulary acquisition through online game. After the data from the questionnaire were collected, the participants were interviewed to look for more information and clarifications based on the responses of the participants in the questionnaire. Thus, the interview participants had to give a "free commentary" (Secord \& Peevers, 1974) on a few carefully constructed prompts on vocabulary and online game.

Content analysis used to identify participants' patterns related to certain themes of their perspectives about vocabulary acquisition through online game. The first step of analyzing data was processing the data gathered from the questionnaires. The data collected from close-ended questionnaires were analyzed using Microsoft Excel and SPSS. The researcher find out the score from each item in the questionnaire. Table 1 presents the Likert Scale and the converted score

Table 1 : The Converted Score of the Frequency

\begin{tabular}{|c|c|}
\hline Frequency & The converted Score \\
\hline Never & 1 \\
\hline Rarely & 2 \\
\hline Sometimes & 3 \\
\hline Often & 4 \\
\hline Always & 5 \\
\hline
\end{tabular}

The score ranged from 1 to 5 . Here is the formula, as follows: 
Score $=\frac{\sum[(F .1]+(F .2)+(F .3)+(F .4)+(F .5)]}{\sum N}$

Note :

F : The number of students based on the degree of frequency

$\sum \quad$ : The number of total participants

The questionnaire items were classified into five categories, namely determination strategies, social strategies, memory strategies, cognitive strategies and metacognitive strategies. The data from open-ended questionnaire were also classified into those categories. Next, the statistical data was figured and described by words so that the researcher and the reader would understand the finding better.

\section{RESULT AND DISCUSSIONS}

As stated in the preceding chapter, this research is focused on students' perception to vocabulary acquisition through online games by the fourth semester students of foreign language academy UMI. Below are the collected data during the study and discussion on them. First the authors shared the questionnaire with students after the authors explained the contents of the authors' questionnaire.

Table 4.1

Distribution of Respondents by Gender

\begin{tabular}{|c|c|c|}
\hline Gender & Frequency & \% \\
\hline Male & 18 & 60 \\
Female & 12 & 40 \\
\hline Total & $\mathbf{3 0}$ & $\mathbf{1 0 0}$ \\
\hline
\end{tabular}

Data 2019

Based on table 4.1 shows that respondents who are male are $60 \%$ and female is $40 \%$

Table 4.2

Distribution of Respondents by Age

\begin{tabular}{|c|c|c|}
\hline Gender & Frequency & \% \\
\hline 20 & 12 & 40 \\
21 & 14 & 46,7 \\
22 & 4 & 13,3 \\
\hline Total & $\mathbf{3 0}$ & $\mathbf{1 0 0}$ \\
\hline
\end{tabular}


Data 2019

Based on table 4.2 shows that respondents the age of 20 years is 12 (40\%), age of 21 years is $14(46,7 \%)$, and age of 22 years old is $4(13,3 \%)$.

Table 4.3

Distribution Opinion Students About Vocabulary Trough Online Game

\begin{tabular}{|c|c|c|c|c|c|c|}
\hline \multirow{2}{*}{\multicolumn{2}{|c|}{ Statement }} & \multicolumn{5}{|c|}{$\begin{array}{l}\text { ALTERNATIVE ANSWERS AND } \\
\text { SCORE VALUE }\end{array}$} \\
\hline & & Never & Rarely & Sometimes & Often & Always \\
\hline & $\begin{array}{l}\text { I understand the meaning } \\
\text { of new vocabulary by } \\
\text { hitting or guessing the } \\
\text { meaning of the word } \\
\text { according to the context } \\
\text { in the game }\end{array}$ & & & $\begin{array}{c}12 \\
(40 \%)\end{array}$ & $\left|\begin{array}{c}17 \\
(56,7 \%)\end{array}\right|$ & $\begin{array}{c}1 \\
(3,3 \%)\end{array}$ \\
\hline & $\begin{array}{l}\text { I understand the meaning } \\
\text { of new vocabulary when } \\
\text { playing games }\end{array}$ & & $\begin{array}{c}1 \\
(3,3 \%)\end{array}$ & $\begin{array}{c}11 \\
(36,7 \%)\end{array}$ & $\begin{array}{c}18 \\
(60 \%)\end{array}$ & \\
\hline & $\begin{array}{l}\text { I made a new vocabulary } \\
\text { list when playing games }\end{array}$ & & & $\begin{array}{c}13 \\
(43,3 \%)\end{array}$ & $\mid \begin{array}{c}17 \\
(56,7 \%)\end{array}$ & \\
\hline & $\begin{array}{l}\text { I remember the new } \\
\text { vocabulary by finding } \\
\text { synonyms from the word } \\
\text { when playing the game }\end{array}$ & & $\begin{array}{c}6 \\
(20 \%)\end{array}$ & $\begin{array}{c}14 \\
(46,7 \%)\end{array}$ & $\left(\begin{array}{c}10 \\
(33,3 \%)\end{array}\right.$ & \\
\hline & $\begin{array}{l}\text { I remember new } \\
\text { vocabulary when playing } \\
\text { games by } \\
\text { spelling }\end{array}$ & & $\begin{array}{c}4 \\
(13,3 \%)\end{array}$ & $\begin{array}{c}16 \\
(53,3 \%)\end{array}$ & $\begin{array}{c}10 \\
(33,3 \%)\end{array}$ & \\
\hline 6 & $\begin{array}{l}\text { I am easier to master the } \\
\text { new vocabulary when I } \\
\text { see images in the game }\end{array}$ & & $\begin{array}{c}7 \\
(23,3 \%)\end{array}$ & $\begin{array}{c}14 \\
(46,7 \%)\end{array}$ & $\begin{array}{c}9 \\
(30 \%)\end{array}$ & \\
\hline 7 & $\begin{array}{l}\text { I use new words in } \\
\text { sentences that I know } \\
\text { from online games }\end{array}$ & & $\begin{array}{c}3 \\
(10 \%)\end{array}$ & $\begin{array}{c}11 \\
(36,7 \%)\end{array}$ & $\begin{array}{c}15 \\
(50 \%)\end{array}$ & $\begin{array}{c}1 \\
(3,3 \%)\end{array}$ \\
\hline 8 & $\begin{array}{l}\quad \text { made } \quad \text { a r new } \\
\text { vocabulary list } \begin{array}{r}\text { and } \\
\text { wrote the translation in }\end{array} \\
\text { Indomonom }\end{array}$ & & $\begin{array}{c}2 \\
(6,7 \%)\end{array}$ & $\begin{array}{c}18 \\
(60 \%)\end{array}$ & $\begin{array}{c}8 \\
(26,7 \%)\end{array}$ & $\begin{array}{c}2 \\
(6,7 \%)\end{array}$ \\
\hline
\end{tabular}


ELT Worldwide Vol. 6 No. 2 (2019)

Angraeni, Chuzaimah, Nasir : Investigating EFL Students' Perception ...

\begin{tabular}{|c|c|c|c|c|c|}
\hline 9 & $\begin{array}{l}\text { I recorded a new } \\
\text { vocabulary from what I } \\
\text { saw in online games }\end{array}$ & $\begin{array}{c}4 \\
(13,3 \%)\end{array}$ & $\begin{array}{c}15 \\
(50 \%)\end{array}$ & $\begin{array}{c}11 \\
(36,7 \%)\end{array}$ & \\
\hline 10 & $\begin{array}{l}\text { I learned new vocabulary } \\
\text { from online games }\end{array}$ & & $\begin{array}{c}7 \\
(23,3 \%)\end{array}$ & $\begin{array}{c}13 \\
(43,3 \%)\end{array}$ & $\begin{array}{c}10 \\
(33,3 \%)\end{array}$ \\
\hline 11 & $\begin{array}{l}\text { I am looking for new } \\
\text { vocabulary meanings } \\
\text { using an electronic } \\
\text { dictionary when playing } \\
\text { anlino anmos }\end{array}$ & $\begin{array}{c}2 \\
(6,7 \%)\end{array}$ & $\begin{array}{c}13 \\
(43,3 \%)\end{array}$ & $\begin{array}{c}15 \\
(50 \%)\end{array}$ & \\
\hline 12 & $\begin{array}{l}\text { I made a plan to learn } \\
\text { new vocabulary through } \\
\text { online games }\end{array}$ & & $\begin{array}{c}15 \\
(50 \%)\end{array}$ & $\begin{array}{c}14 \\
(46,7 \%)\end{array}$ & $\begin{array}{c}1 \\
(3,3 \%)\end{array}$ \\
\hline
\end{tabular}

\section{Discussion}

The primary purpose of this study was to examine students' perceptions of Project-Based Learning implementation in the classroom. There is still a lack of research perceptions of PBL in Indonesia, especially in the Critical reading class and collected data to determine if PBL has positive impacts on students learning in public colleges. This study has a different focus from other previous research, so the findings are also different.

Item 1, Students who understand the meaning of the new vocabulary by guessing the meaning of the word according to the context in the game are often as many as 12 students (40\%) and those who choose the least 1 students (3,3\%). Item 2, Students who understand the meaning of the new vocabulary when playing game are often chosen as many as 18 students (60\%) and those who choose the least are 1 students (3,3\%). Item 3, Students who make a new vocabulary list when playing games are often as many as 17 students $(56,7 \%)$ and those who choose the least are as many as 13 students (43,3\%). Item 4, Students who remember the new vocabulary by searching for synonyms from the words when playing game that most sometimes choose 14 students $(46,7 \%)$ and those who choose the least are as many as 6 students (20\%). Item 5, students who remember the new vocabulary when playing games with the most spelling methods often have 16 students $(53.3 \%)$ and at least rarely choose as many as 4 students $(13, \%)$. Item 6 , students who are easier to master the new vocabulary when viewing images in the most games are sometimes as many as 14 students (46.7\%) and those who seldom choose rarely are 9 students (23.7\%). Item 7, students who use the new word in the sentence that I know from the most chosen online game are 15 students $(50 \%)$ and those who choose the least number are 1 student $(3.3 \%)$. Item 8 , the students who made a list of new vocabulary words and wrote their exposures in the Indonesian language that chose the most were sometimes as many as 18 students $(60 \%)$ and those who chose the least and always the least were 2 students $(6.7 \%)$. Item 9, students who recorded the new vocabulary from what I saw in the online game that most often chose were 15 
students $(50 \%)$ and those who seldom selected as many as 4 students $(13.3 \%)$. Item 10, the students who learn the new vocabulary from the most online games often choose 13 students (43.3\%) and those who seldom choose as many as 7 students $(23.3 \%)$. Item 11, students who are looking for new vocabulary meanings by using electronic dictionaries when playing online games that choose the most often are 15 students $(50 \%)$ and those who seldom choose rarely are 2 students (6.7\%). And finally item 12 , students who make plans to learn new vocabulary through online games are the most chosen sometimes as many as 15 students $(50 \%)$ and those who choose the least are as many as 1 student $(3.3 \%)$.

\section{CONCLUSIONS, IMPLICATION, AND SUGGESTIONS}

Based in data analysis, it can be drawn conclusion that result of the research about 'Investigating Students' Opinion On The Learning English Vocabulary Through Online Game at Foreign Language Academy of UMI" Based on the 12 items above the most chosen by students is item 2 and 8 , students who understand the meaning of new vocabulary when playing games and Student who made a new vocabulary list and wrote the translation in Indonesian are the opinions most chosen by students with an occasional scale of $60 \%$.

\section{REFERENCES}

Arham, M., Akrab, A.H. (2018). Delving into Delving into Content Lecturers' Teaching Capability in Content Language Integrated Learning (CLIL) at an Indonesian University, Asian ESP Journal, Vol. 14 No. 7.2 (2018).

Collins, William, 1979, Webster's New Twentieth Century Dictionary, America: The United States of America.

Edward, 2006, Synthetic Worlds: The Business and Culture of Online Games, Chicago: University Of Chicago Press.

Elfrieda H. Hiebert and Michael L. Kamil. 2005. Teaching and Learning Vocabulary: Bringing Research. Volume 18 No. 1 April 2006 ISSN 15390578.

Eskelinen, Satu, 2012, Applying Video Games In Language Learning and Teaching, Rusia : University of Jyväskylä

Eugene, Hall J, 1993, Grammar for Use, Jakarta: Bina Rupa Aksara.

Hong, Lin, 2002., Using Games In Teaching English To Young Children, ELT Journal.

Hornby, A.S, 2013, Oxford Advanced Learner's Dictionary of Current English, Oxford: Oxford University Press

Lubis, Ika Rahmadani 2017, Improving Students' Vocabulary Mastery By Using Fly Swatter Game In The First Grade Of Mts Persatuan Amal Bakti (Pab) 1 Helvetia, Medan: State Islamic University Of North Sumatera.

L. Beck, Margaret G, 1989, Learning From Social Studies Text, New York. 
Lestari, Wiji, (2013), Improving Students' Vocabulary Mastery Through Word Clap Game, Salatiga: English Department of Educat ion State Institute for Islamic Studies (STAIN) of Salatiga.

Marianne Celc e-Murcia. 2001. Teaching English as a Second or Foreign Language, USA: Heinle \& Heinle.

Nation. 1994. New Ways in Teaching Vocabulary. Alexanderia: TESOL. Random House Webster's Collage Dictionary. 2001. USA: Unites State of America.

Schmitt, Norbert, 2000, Vocabulary in Language Teaching, New York: Cambridge University Press

Sepherd, David L. , 1982, Comprehensive High School Reading Methods, Columbus: Merril.

Siek-Piskozub Teresa, 1995, Gry, Zabawy i Symulacje w Procesie

Glottodydaktycznym, Poznań: Wydawnictwo Naukowe UAM.

Toth, M, 1995, Children's Games, .Oxford: Heinemann Publishers.

Read, John, (2000), Assessing Vocabulary, Cambridge UK: Cambridge University Press

Rollings, Andrew; 2006, Fundamentals of Game Design, Prentice Hall. 